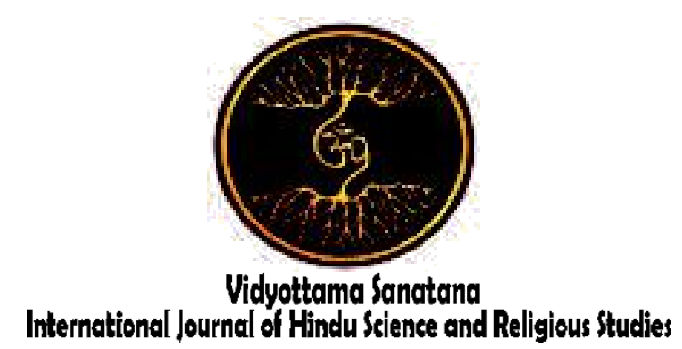

Vol. 2 No. 2 October 2018

\title{
The Role Of Lontar Digitalization For Hinduism Informal Education In Preserving Cultural And Hinduism At The Puri Gede Kerambitan Tabanan
}

\author{
By: \\ I Putu Putra Yasa', I Nengah Duija ${ }^{2}$, I Wayan Wastawa ${ }^{3}$ \\ ${ }^{123}$ Institut Hindu Dharma Negeri Denpasar \\ E-mail: ${ }^{1}$ ipt.putra@yahoo.com
}

Received: July 18, 2018

Accepted: September 28, 2018

Published: October 31, 2018

\begin{abstract}
Bali having many literary work in form of lontar which is stored in a library or collection of personal. Overall, it cannot be known for certain but mostly to lack of care. The lontar contain to the transcendent value the teachings of Hinduism that can be implemented in life. This research revealed about the preservation of cultural and Hinduism through the efforts of lontar digitalization which is then associated with the role of Hinduism informal education especially at Puri Gede Kerambitan. The focus of research are: lontar digitalization process, the role of the lontar digitalization to Hinduism informal education, and the efforts that supports lontar digitalization. The purpose of this research are: provides a description of lontar digitalization at Puri Gede Kerambitan, explaining the role of the process of lontar digitalization to Hinduism informal education and provides a description of supporting efforts lontar digitalization. Disclosure of research results was done through qualitative arguments. The results of this study indicate that are (1) Lontar is cultural documentation of the past that is highly valued. The preservation of lontar by doing lontar digitalization can provides a description about the conversion of the lontar into the form of digital image by using digital equipments. Lontar digitalization as a positive step to save the literature about culture and Hinduism that is highly valued; (2) Lontar digitalization has a positive for the process of Hinduism informal education by applying values of Hinduism directly during the performance of lontar digitalization; (3) Puri Gede Kerambitan gives full support to the lontar digitalization process that has been conducted by outsiders. But the Government support is still not maximum yet to the preservation of culture and Hinduism. The efforts made by various parties were the overview of insights and viewpoints that support the preservation of lontar through lontar digitalization.
\end{abstract}

Keywords: lontar digitalization, Hinduism informal education, the preservation of culture and Hinduism 


\section{Introduction}

Culture in the life of Balinese people is attached closely to the teachings of Hinduism. One form of culture from an ancestor in the past can be seen in ancient manuscripts written well on the rock media as well as the media leaves that is lontar. It's interesting that the Balinese people have known the latest technology in his day by creating written works on the leaves of the lontar. Most kinds of lontar in Bali now can still be found in certain places, such as in certain temples, in the puri, in the brahmanas family, in the college library, in the museum of literature or culture and also some other place of which the owner is still preserve the lontar. As mentioned in the book Kakawin Deúa Warónana uthawi Nàgara Kåtàgama : Masa Keemasan Majapahit that in bali many stored of a literary work in the form of the lontar for example in the Gedong Kirtya Buleleng, Documentation Bali Cultural Center (Pusdok) Denpasar, as well as Library Of The Faculty Of Letters Udayana University Bali (Riana, 2009: 3). Lontar not only can be found in Government institutions but also may be found or owned by a library or own collection. Cannot be known with certainty the number of ancient lontar that was stored in museums, Estimated reaching thousands even tens of thousands.

There are so many of lontars especially belonging to individuals not registered due to several factors, including: (1) lontar is "pingit" or sacred so only certain people considered great and elected capable of taking and read it, (2) Lacking concern Balinese people against the lontar because lack of knowledge or inability people to read and understand the contents of the lontar, (3) the limitations of the program and budget of the Government or related agencies so the lontar also less of attention. In fact to preserve the lontar not enough to do logging only but it can grow the interest and attention of the Balinese it is fundamental in an effort to save culture and Hinduism in this era of globalization.

The era of globalization is a challenge for the existence of culture especially lontar. With the rapid advancement of technology and information, lontar will get less attention even be forgotten. Most people have a tendency to regard the lontar is ancient things and having no value benefits anymore for them compared to using sophisticated equipment available today. The existence of the lontar will be more worrying when noble values contained therein recognized and patented by other parties then people start was struck to get back and start from the beginning to keep the culture.

Science and information technology not only gives pleasure that changes the order of human life, but it could become the basis of innovation to the lontar. Lontar digitalization is an innovation by making use of science and technology to converting the lontar into digital form either photographic or the script. Conversion of lontars into digital form is very important in this era of information-based. Even more significantly the results of the lontar digitalization having the benefit in daily life especially in the field of education. Science can be disseminated through education so as to foster a human sense of self. Human sense of self was instrumental in sorting and selecting good benefits and useful to themselves and society at large.

As for problems that can be formulated as follows: (1) How does the process of lontar digitalization in Puri Gede Kerambitan Tabanan?. (2) How does the role of lontar digitalization for Hinduism informal education in Puri Gede Kerambitan, Tabanan?. (3) Whether efforts undertaken by Puri Gede Kerambitan Tabanan, outside parties and the Government in supporting the process of lontar digitalization as a form of cultural preservation and Hindu religious?.

The purpose of this research include: (1) Describes the process of lontar digitalization in Puri Gede Kerambitan to digital form. (2) Reveal the role of lontar digitalization, especially to the Hinduism informal education in Puri Gede Kerambitan Tabanan. (3) Describe the efforts made by Puri Gede Kerambitan Tabanan internally, as 
well as the efforts of outside parties and the Government, especially in supporting the process of lontar digitalization as a concrete manifestation preservation of cultural and Hinduism.

\section{Method}

In methodologically, the study is done through a method of qualitative approach. Puri Gede Kerambitan Tabanan who has a lot of lontar collection selected as a location for research because of the friendliness and attitude of openness to the ideas of preservation of lontar. The kind of data that is used in this research is qualitative data obtained from primary and secondary. Researcher acting as the main instrument of the most reliable because the researcher are full participant in a research in the field. The selection of informants is determined by purposive by picking the key informants to enhance the usefulness of information in research. A technique that is used to collect the data is through observation, interviews and the literature study. Data were analyzed using descriptive qualitative technique by using digital image formation theory, the theory of functionalism and theory of phenomenology later served as systematically arranged in order to ease in pulling summary

\section{Results and Discussion}

Lontar is a form of ancient manuscripts and many are found particularly in Puri Gede Kerambitan Tabanan. According to the Head Sub-division of Maintenance and Repair of References in Conservation Division, at the center of the Preservation of the National Library of the Republic of Indonesia "Said the lontar derived from 'ron' and 'tal' ... This rooted in a word of the 'ron' (leaf) and 'tal' (tree)" (Wirayati, 2011: 1)

Observing the quote that lontar is made from the leaves of a palm tree which has undergone various phases of the process to be used as a writing medium. Before the leaves can be used as a writing medium, the leaves are first created in the form of sheet and requires a complex process of preserving. With those techniques, most of ancient manuscript could still survive and can be found in several places until now. The others have been damaged due to humidity factor, edible similar termites and other small insect, then the factor in human resources that do not have specific knowledge about the care of lontar and other factors.

Before the occurrence of an increased number of collections that have been damaged as well and even lost, need to be preservation of lontar is by carrying out lontar digitalization using digital devices. Lontar digitalization is the effort changing the lontar media to digital form of digital image or digital glyphs. In this research, lontar digitalization is performed to get the results in the form of digital images. It can be said the technology becomes a means to documenting, preserving, conserving and spreading of culture. The result of this lontar digitalization is a digital image which is a digital documentation of the original lontar. With the documentation means lontar has been preserved because there is a copy of the original lontar may be freely copied in digital form. Implement the lontar digitalization and preservation of lontar is doing as well as can disseminate culture through the palmyra in the form of a digital image.

Lontar digitalization process conducted by some stages among them: (1) data acquisition is the process to get the data in the form of images, in this study using a digital camera; (2) the images then get treatment image processing using computer complete with pictures application; (3) images that have undergone processing images can be stored on a digital storage media as an archive if at any time it takes to do the processing of return or for the purpose of disseminated through the transfer of digital data; (4) images that have been processed digitally then viewable on screen viewer or reprinted using the printer image.

The obstacles most prominent in digitalisai lontar among other: (1) Limitation 
of funds. Unpreparedness the lontars owner as partner in providing the lontar and budget constraints for lontar digitalization. (2) Unpreparedness of the human resources in the use of digital equipment and image processing applications. (3) Shooting obstacles, namely the results obtained often blur or shade. Thus really need quite a long time because it is still relies entirely to use of the assistance of the operator in addition to using the tools and the techniques of shooting a still modest. (4) Nonstandard data formats that could complicate the possibility of mutual access between users.

While the settlement in overcoming and minimize the impact of the barriers mentioned above, namely: (1) Collection and source of funding obstacles can be overcome by selectively choose partner having attitude openess wiiling continuing program of research and are willing to continue lontar digitalization programs as agreed upon. (2) Human resource issues in lontar digitalization can be solved by do the coaching or training for the operator or researchers in using digital equipment. (3) Minimize operator assistance in taking pictures by using a tripod and a timer automatically reducing the shaded. (4) Doing a deal on data format used between fellow users of the end result. The data format is varies from image processing applications used, commonly used in the form of .jpeg or .jpg to ease in storage and distribution.

Puri Gede Kerambitan is very open to ideas of conservation and welcomed the idea of lontar digitalization. With unsettled lontar digitalization apparently increasingly excite and maintaining an attitude of all members of the Puri Gede Kerambitan to be welcomed every thing that will bring a positive impact with regard to the advancement and the good living society. Slowly but surely, Puri Gede Kerambitan openness toward positive things that make each member of Puri Gede Kerambitan to always participate actively to be friendly, good manners and show everything that is good against one another formed character culture and educated Hinduism. On the other hand each of the parties involved in this study, realized or not directly apply the teachings of the Hindu religion, that is performing self control during the lontar digitalization. Informally this activity more emphasis on moral education and its restraint in accordance with the teachings of Hinduism. This can be a reflection for society to imitate an attitude of openness and friendliness of Puri Gede Kerambitan. Thus during the process of converting into digital form, lontar digitalization having role in Hinduism informal education especially in Puri Gede Kerambitan. Puri Gede Kerambitan strongly supported the efforts of preservation of lontar, because of the many education values and teachings of Hinduism that imaginary in lontar so it is very useful to be implemented.

There are efforts undertaken by Puri Gede Kerambitan, parties from the outside and Government. As real Puri Gede Kerambitan strongly support the ideas and implementation of conservation carried out by parties from outside as well as Government. Puri Gede Kerambitan as owners do regular maintenance of the lontar and provides storage space in order for the lontar can last longer. From outside parties doing well converting lontar into digital images, also make copies and the script of lontar. The Government provides the facilities of a library or lontar documentation centre as well as storage and as a place to study and do research for researchers and academics. But the attention of the Government directly to the owners of the lontar especially Puri Gede Kerambitan is still low. The owner of lontar especially individually do not have the facilities and the ability of competent human resources to perform maintenance on the lontar, so the treatment is done with simple and sometimes potluck. This should be of particular concern for the Government because it will impact the existence of lontar as documentation of culture and Hinduism.

\section{Conclusions}

Based on exposure to the role of lontar digitalization for Hinduism informal 
education in preserving cultural and Hinduism at Puri Gede Kerambitan Tabanan, the following conclusions can be drawn: (1) Lontar is the cultural documentation of the past that is highly valued. The preservation by doing lontar digitalization can provides a description of the lontar conversion into the digital picture using digital tools. Lontar Digitalization as a positive step to save teaching sources about culture and Hinduism which is highly valued. (2) Lontar digitalization has a positive for the process of Hinduism education informally by applying the values of Hinduism directly during the performance of digitalization. In particular the Puri Gede Kerambitan apply the attitude of openness and warmth during the performance of digitalization. (3) Puri Gede Kerambitan gave full support to the process of lontar digitalization that has been conducted by outsiders. But at the other side the support of Government is still not maximum to the preservation of culture and Hinduism. Efforts undertaken is an overview of the various parties in supporting the preservation through lontar digitalization.

\section{References}

Koesoema A, D. 2007. Pendidikan Karakter: Stategi Mendidik Anak di Zaman Global. Ariobimo, Ed. Jakarta: Grasindo.
Moleong, L.J. 2011. Metodologi Penelitian Kualitatif (Edisi Revisi). Jakarta: PT. Remaja Rosdakarya.

Picard, M. 2006. Bali: Pariwisata Budaya dan Budaya Pariwisata. Jakarta: KPG (Kepustakaan Populer Gramedia) bekerja sama dengan Forum Jakarta-Paris dan École Française d'Extrême-Orient.

Riana, I.K. 2009. Kakawin Deúa Warónana uthawi Nàgara Kåtàgama : Masa Keemasan Majapahit. Citrawati, N.P.E.W., Ed. Jakarta: PT Kompas Media Nusantara.

Sudiapermana, E. 2011. Model Pengukuran Sosial Pada Pendidikan Nonformal dan Informal. Jakarta: Nagara.

Wahono, Romi Satria. 2006. Teknologi Informasi untuk Perpustakaan: Perpustakaan Digital dan Sistem Otomasi Perpustakaan, [diakses pada 04 Agustus 2012]. Jakarta: IlmuKomputer.Com. tersedia pada URL:

http://www.ilmukomputer.org/wpcontent/uploads/2006/09/romiotomasiperpustakaan15september2006.pdf

Wirayati, Made Ayu. 2011. "Konservasi Manuskrip Lontar, Agustus, 2011”. Visi Pustaka, Vol. 13 No. 2. 